\title{
Non-correlation between CRP and rapid diagnostic tests for malaria among rural population in Southern Uganda (Original research paper)
}

\author{
B. Silhar (Barbara Silhar)', D. Dorko (Dominik Dorko)', B. Durcova (Barbora \\ Durcova)', N. Bujdova (Natasa Bujdova)2, 5. Spanik (Stanislav Spanik)², J. Polonova \\ (Jaroslava Polonova) ${ }^{2}$, V. Krcmery (Vladimir Krcmery)² J. Suvada (Jose Suvada) ${ }^{1}$
}

${ }^{1}$ St. Bakhita and Health Initiatives for Africa project, Uganda

Original Article

${ }^{2}$ Outstation in Nairobi, Kenya

\section{E-mail address:}

barbara.silharova@gmail.som

\section{Reprint address:}

Barbara Silhar

Health Initiatives Associate, St. Elisabeth University of Health and Social Sciences

Tropic programme

Buikwe, Uganda

Suource: Clinical Social Work and Health Intervention

Pages: $31-33$
Volume: 8

Issue: 3

\section{Reviewers:}

Vitalis Okoth

Mary Immaculata and VCT Ctr Nairobi, Kenya

Dadline Kisundi

St. Bakita and St. Kizito Ctr Nairobi, Kenya

\section{Key words:}

C-reactive protein, CRP, Malaria, Rapid diagnostic tests, Diagnostics of malaria, RDT.

\section{Publisher:}

International Society of Applied Preventive Medicine i-gap

CSWHI 2017; 8(3): 31 - 33; DOI 10.22359/cswhi_8_3_06 (C) 2017 Clinical Social Work and Health Intervention

\section{Abstract:}

The correlation between CRP blood levels and clinical presentation of malaria or blood parasitemia diagnosed microscopically or by PCR is one of the most discussed topics in the field of tropical medicine and malaria diagnostics. In total, 650 patients from the Lake Victoria area, 
which is of high risk for malaria were included in this study. In patients with febrile episodes, CRP tests were done together with the RDT for malaria. In 239 cases with CRP positive malaria, only 119 (51\%) showed RDT malaria positive. CRP does not correlate with proven RDT for malaria. Patients with fever due to infection caused by Pl. falciparum can be CRP negative and vice versa, CRP positive patients may have negative RDT for malaria.

\section{Conflict of interest:}

The authors whose names are listed in the title of the article certify that they have NO affiliations with or involvement in any organization or entity with any financial interest (such as honoraria; educational grants; participation in speakers' bureaus; membership, employment, consultancies, or other equity interest), or non-financial interest (such as personal or professional relationships, affiliations, knowledge or beliefs) in the subject matter or materials discussed in this manuscript.

\section{Introduction}

South East Uganda has a significant migrating (IDP and refugees) population. This is mainly due to the instability of surrounding countries and famine in South Sudan, Northern Kenya and Nigeria. At the same time, being near Victoria Lake makes this area high risk of malaria due to the proximity of the water source and the altitude. RDTs are often a useful diagnostic tool for malaria, HIV and other infectious diseases where RDTs are available. Lack of resources, staff and infrastructure make them ideal for "field conditions". Moreover, CRP is also a relatively cheap and available diagnostic option for patients with fever. The correlation between CRP positivity and RDT positive malaria test could be lifesaving. The aim of this study was to assess whether a correlation exists in this area of rural settings with highly vulnerable population.

\section{Patients and methods}

651 patients presented with fever at the local OPD center. In the diagnostic algorithm, also malaria RDT and CRP tests were done. Patients with positive RDT underwent microscopic confirmation of malaria parasites. Statistical correlation for CRP and RDT positive patients was performed with $\mathrm{x}^{2}$ test and EPI-info statistical package was used for evaluation of the results.

Table 1: Patients with fever and diagnostics of malaria in Buikwe, South East Uganda

\begin{tabular}{|l|l|}
\hline Total & 605 \\
\hline $\mathrm{CRP}<20$, MPS,- RDT - & 297 \\
\hline $\mathrm{CRP}<20, \mathrm{MPS}+$, RDT + & 18 \\
\hline $\mathrm{CRP}>20, \mathrm{MPS}-$, RDT- & 185 \\
\hline $\mathrm{CRP}>20, \mathrm{MPS}+$, RDT + & 103 \\
\hline $\mathrm{CRP}>20, \mathrm{MPS}+$, RDT- & 1 \\
\hline $\mathrm{CRP}<20$, MPS-, RDT + & 1 \\
\hline
\end{tabular}

\section{Results and discussion}

Among 650 patients, 178 had microscopically confirmed malaria $(27.38 \%)$. Of those, 103 (57.87\%) had also CRP blood level elevated $>50 \mu \mathrm{g} / 1$. Of the $297 \mathrm{ma}-$ laria negative patients, 183 had CRP elevated above $50 \mu \mathrm{g} / 1$, probably due to the 
bacterial infection (all above $50 \mu \mathrm{g} / 1$, median $71.33 \mu \mathrm{g} / 1$ ). Therefore, we can say that CRP elevation is not typical for malaria and threshold $20 \mu \mathrm{g} / 1$ cannot be predictable for malaria diagnostics. In some studies threshold is even $100 \mu \mathrm{g} / 1$ ().

\section{Conclusion}

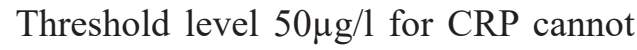
be predictive marker for malaria diagnostics in endemic region, such as South East Uganda. Patients with a CRP level above $50 \mu \mathrm{g} / 1$ did not have significantly more positive RDTs for malaria and vice versa.

\section{References}

1. KOMLOSI M, AHISHAKIYE Z, NIYIBAMPA R, RWASA T, MPAWENAYO A (2017) Comparison between Microscopy and PfHRP2 based RDT for diagnosing Tropical Malaria in Febrile Patients in Mesoendemic Malaria Transmission Area of Rural Burundi, among Internally Displaced Populations after Tribal Conflicts. Clinical
Social Work and Health Intervention Vol. 8 No. 22017.

2. MOLNAROVA K, WOLF S, TENNA M (2016) Highland malaria at the Kiziba UNHCR refugee camps (1950m. a. s.). Clinical Social Work and Health Intervention Vol. 7 No. 32016.

3. KIMULI D,CZARNECKI P, MIKLOSKOVA M, SPANIK S, BRYNDZAK $P$ et al (2016) Social pathology II. WMU WARSAW. 2016. 455 pp.

4. RIDOSKO J (2014) Treatment of intra-articular femur fractures. Radix, spol. s. r. o. ISBN 978-80-87573-09-9.

5. PAUL R, SINHA PK, BHATTACHARYA R, BANERJEE AK, RAYCHAUDHURI P, MONDAL J (2012) Study of C reactive protein as a prognostic marker in malaria from Eastern India. Advanced Biomedical Research, 1, 41. http://doi.org/10.4103/22779175.100140.

6. HAGHIGHI L (1969) C-Reactive protein in malaria. Journal of Clinical Pathology, 22(4), 430-432. 